\title{
Arab Banks during Tranquil and Turbulent Times: A Reflection of Arab Economies
}

\author{
Saeed Al-Muharrami \\ Associate Professor, Dept. of Economics and Finance, College of Economics and Political Sciences, \\ Sultan Qaboos University, P.O.Box 20, Al-Khod 123, Sultanate of Oman \\ Email:muharami@squ.edu.om
}

\section{Doi:10.5901/mjss.2015.v6n4p200}

\begin{abstract}
Can Banks' statistics, indicators, performance, and efficiency provide us with any indications about the causes of Arab Spring? This paper examines the 74 banks' perspective on of Arab countries, where the Arab Spring occurred in Egypt, Libya, Syria, Tunisia and Yemen, versus 241 banks in other fifteen Arab countries. The paper analyzed the aggregate balance sheet items and income statement entries as well as recent trends in total assets, deposits, equity, and net income growth. The paper also examines the evolution of 315 Arab banks over 14 years from 1997 to 2010 of many ratios including Asset quality, capital, operations, and liquidity, and financial soundness. The results show that the majority of banks in the five countries were below the average in their performance. Their ranking, regionally and globally, in terms of the size, performance, and efficiency were weak. The regional and world ranking of these banks gives a glance about the business atmosphere and the economic conditions at these five countries.
\end{abstract}

Keywords: Arab countries; Arab banking; Arab Spring; banks' performance, banks' ranking, accounting ratios.

\section{Introduction}

The Arab Spring refers to the crop of pro-democracy uprisings in 2011 sweeping the Arab countries in the Middle East and North Africa. The Arab Spring began in Tunisia, with the self-immolation of a vegetable seller outside a government building in protest at police harassment. This kicked off a wave of protests that ended with the ouster of Tunisian president Ben Ali. Similar protests soon followed around the Middle East and North Africa region. As result of those protests, the presidents of four Arab countries were changed: Ben Ali president of Tunisia, Mubarak president of Egypt, Ali Abdullah Saleh president of Yemen, Muamar Qadhafi president of Libya. At the time of writing, there have been demonstration and fighting in Syria aiming to change the presidency of Bashar Al-Assad. The putative aim of the Arab Spring was to overthrow oppressive dictatorships and hopefully bring in more accountable democratic governments which would put the interests of people first rather than just the interest of the ruling family.

What were the main reasons for the Arab spring? Were the causes primarily political? Or were the economic factors the main motive? Or, was it a combination of socio-economic factors, what were the indicators of that? If, it was economic, were there any indicators signifying the problem might happen soon? Since banks are the main financial institutions in any country, including Arab countries, would their statistics, indicators, performance and efficiency provide us with any indications about the causes of the Arab Spring? Therefore, the aim of this paper is to read and to analyse some of the socio-economic statistics with an emphasis on analysing the size, efficiency and performance of Arab banks for a period of 14 years from 1997 to 2010. This interval covers the time before the Arab spring started. The paper examines the banks' perspective on Arab countries especially five countries namely: Egypt, Libya, Syria, Tunisia and Yemen with the aim to answer why the demonstrations occurred in these countries.

The banking system reflects the economy, particularly the private sector, real economy, trade and tourism. The paper argues that banks' performance in a country is a good indicator of the socio-economic conditions in the Arab world. The relative performance of banks in a country to other banks in other countries can tell how good or bad the people's condition is within that country. In the absence of socio-economic indicators, banks' performance indicators can be used as an alternative and give a very close picture about the economic conditions and the investment environment. Good performance of banks indicates the excellent investment climate and the open market of that country. On the other hand, bad performance of banks indicates the poor investment climate and lack of growth as well as a tightly controlled private sector.

The paper is structured into four sections. The remainder of this study is organized as follows. Section II provides the background about Arab banking. Section III illustrates the Performance Indicators and Analysis. Finally, Section IV concludes the study.

\section{Background About Arab Banking}

The Arab world is located in the Continents of Asia and Africa. It comprises 22 countries and it is distinguished by its 
strategic position because it links three continents: Africa, Asia and Europe. It is surrounded by important bodies of water, straits and canals giving it multiple points of access. The population of the Arab World was about 372 million in 2010 with an absolute annual growth of 7.5 million. The most populated country was Egypt with around 84 million representing about $22.55 \%$ of the total Arab population. Comoros was the least populated country with 773,000 people.

Adding to its strategic position, Arab countries are also a source of oil and other mineral resources. Most of the deposits of oil in the world are found in the Arab countries. Saudi Arabia is the largest exporter of oil in the world. Therefore, the Gross Domestic Product (GDP) of many of the Arab countries depends on oil and gas as a main source of their revenue.

Figure 1 represents the relative size of the economies of the Arab countries. The total GDP of the Arab countries was US\$1,903,301 million in 2010. Saudi Arabia, United Arab Emirates and Egypt ranked first, second and third where their total GDP's in 2010 were US\$ 434,440 million, US\$ 239,650 million and US\$216,830 million respectively. Comoros ranked last and its GDP was US\$ 557 million. Most of the top ranked countries with higher GDP's depend mainly on oil and gas as the main source of the country's revenue. The highest GDP's per capita are in the countries of the Gulf Cooperation Council (GCC) namely, Qatar, United Arab Emirates (UAE), Kuwait, Bahrain, Oman and Saudi Arabia being ranked 1 to 6 respectively. Libya, Tunisia, Syria, Egypt and Yemen were ranked 7, 11, 13, 14 and 19 correspondingly.

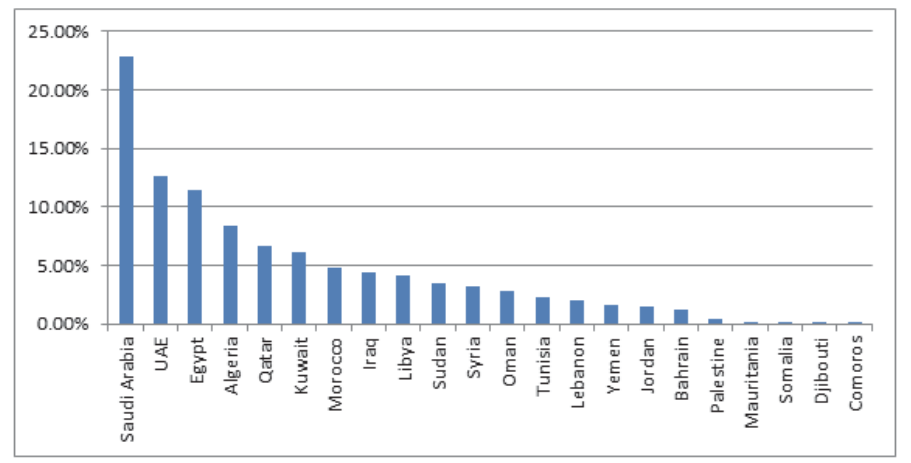

Figure 1: Relative size of the economies of Arab countries Source: Compiled by the researcher from IMF GDP data

In addition, Figure 2 is illustrates the evolution of four financial variables. The first and the second financial variables are the total assets and total equity. Both total assets and total equity kept growing over the 14 year period even during the global financial crisis which affected many financial institutions starting in 2007. There were many reasons for this growth: First, an increase in the accumulation of retained earning where banks maintain the greater portion of their profit to expand in size and to compete with other financial institutions as well as the existence of investment opportunities in some Arab countries specially GCC countries. Second, the increase of oil and gas prices created more liquidity in some Arab banks which enabled them to provide more loans to different economy sectors as well as more loans to households. Third, the existence of investment was expanding in different types of securities such as bonds, shares, and Sukuk for Islamic banks. Fourth, both total assets and total equity kept growing over the 14 years because of the proceeds from stocks offering and borrowing funds.

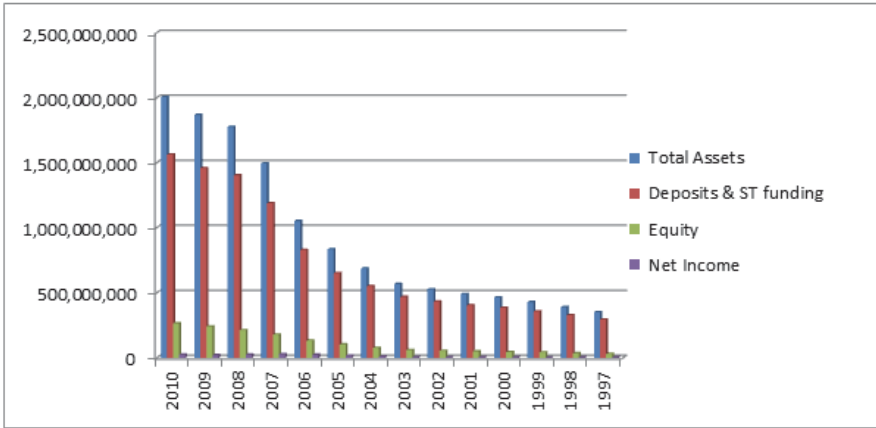

Figure 2: Evolution of some financial variables

Source: Compiled by the researcher from Bankscope 
The third variable, in Figure 2, is the evolution of deposits and short term funding. The sharp increase in this variable could be explained by the higher revenue of some Arab governments and business institutions, in addition to the increased confidence of local and foreign investors. Second, some Arab banks issued different short term debt instruments of bonds and Sukuk. These banks got the investors' confidence in investing in such debt securities. Finally, Figure 2 shows the evolution of the net income variable. The progress of this variable could be divided into four different periods. First, there was slow growth of net income for the period from 1997 to 2003 with an exception for 1999. Second, sharp growth followed the first period in net income from 2003 to 2007. The increase in oil and gas prices had a significant impact on the performance and profit of banks in Arab producing oil and gas countries. Then, there was a sharp decrease in net income from 2007-2009. The performance of most Arab banks was hit by the global financial crisis in 2008 and 2009. Consequently, the overall profit decreased for those two years. However, in 2010 the momentum of growth was back and witnessed a lift up in net income growth.

Analysis of the aggregate balance sheet of 315 commercial and Islamic banks provides us with Figure 3. Looking at the liability side, $78 \%$ of the total liabilities were deposits and short term funding, while equity or the owners' capital represent only $13.2 \%$ of the total liabilities. Even though the owners' capital represents only $13.2 \%$ of the total liabilities, however, Arab banks were meeting the required Capital Adequacy Rate (CAR) of a minimum of $8 \%$ of risk weighted assets set by Bank for International Settlements (BIS). On the assets side, $52.5 \%$ of Arab banks assets were in the form of loans to households, different business sectors, and governments. Out of the total assets, only $1.3 \%$ was fixed assets. $45.1 \%$ of the total assets were invested in different types of investments of which $34.9 \%$ were earning assets and $11.2 \%$ non-earning assets. As we will see when analysing the income statement in Figure 4 most of Arab banks revenue was coming from interest based from loans or from fixed income investment securities. Arab banks invested more in their retail operations during the 14 year period, partly because of the slow pace of corporate lending due to the small size of the private sectors as well as the uncertainty of the global economic outlook.

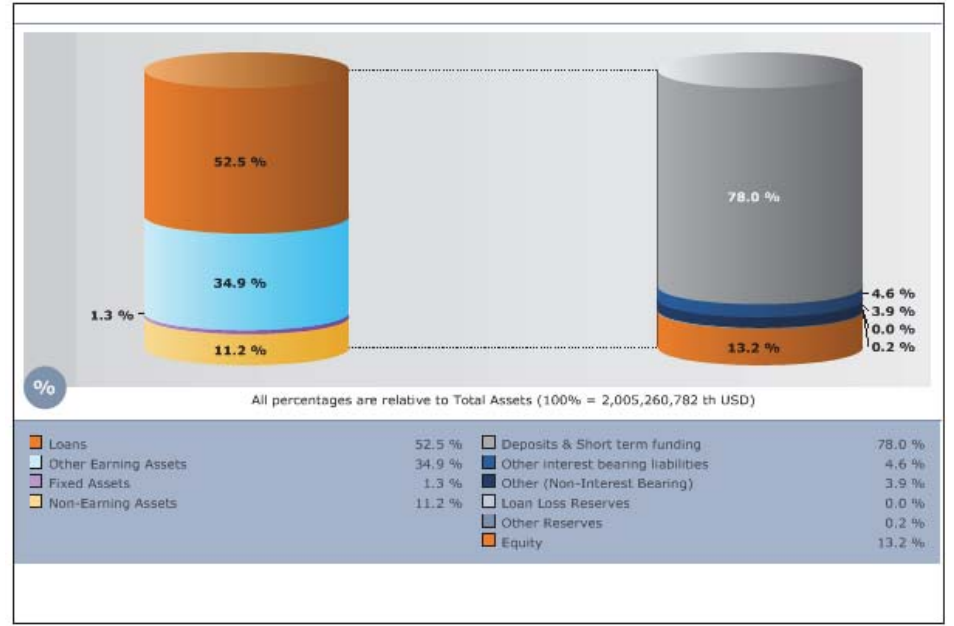

Figure 3: Structure of balance sheet of 315 banks in 2010

Source: Compiled by the researcher from Bankscope

Finally, off-balance sheet activities encompass a variety of items including certain loan commitments, certain letters of credit, and revolving underwriting facilities. Additionally, swaps, futures, forwards and option contracts are derivative instruments whose notional values are carried off-balance sheet, but whose fair values are recorded on the balance sheet.

Figure 4 illustrates the breakdown of the relevancy of the income statement's entries to the operating income. The right side of Figure 4 shows the component of operating income. As shown in Figure 3 of the balance sheet $52.5 \%$ of Arab banks assets were in the form of loans; therefore, $67.9 \%$ of the operating revenue came from interest related revenue. Other operating income represents $32.4 \%$ of the operating income coming from different non-interest related revenues such as different services fees as well as dividends from their share in different investments. On the left side, Figure 4 shows that $39.9 \%$ of the operating income was spent in overheads. $17.7 \%$ of the operating income used on loan loss provisions. Overall, the profit tax in Arab countries, especially GCC countries, is not high; as a result, governments profit taxes represented only $4.9 \%$ of the operating income. After deducting different types of expenses, $35.3 \%$ represent the net income of the operating income. This percentage is considered to be a very good rate. 


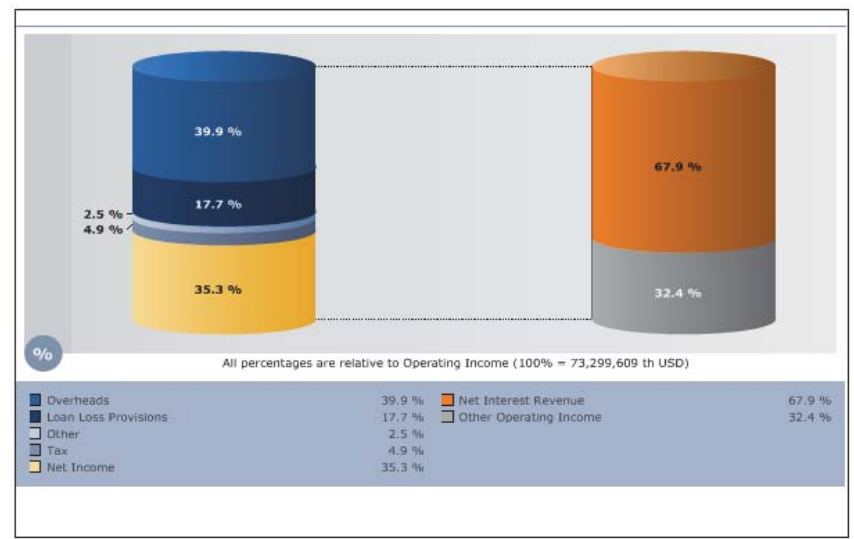

Figure 4: Structure of Profit and Loss Account of 315 banks in 2010

Source: Compiled by the researcher from Bankscope

\section{The Performance Indicators and Analysis}

The total population of Egypt, Libya, Syria, Yemen and Tunisia, hereafter the five countries, represents $39.7 \%$ of the Arab population and the total land area represents $27.5 \%$ of total Arab land. Going back to the question: Can banks give indications of the socio-economic conditions of these five countries relative to other Arab countries? Considering the size of their area, population, strategic location, existing and potential diversified sources of income sources, and their early development compared to many Arab countries, one would expect that these five countries would have the lead among Arab countries in all the indicators including the financial institutions' indicators.

Analysing Table 1, which ranks Arab banks regionally and globally according 2010 data, we can see interesting observations: First, Qatar National Bank was the largest in size measured by its total asset size. This bank was ranked as number one in Qatar and in the Arab World, but its World rank was 255. This finding coincides with Al-Muharrami et. al (2006) that Arab banks are relatively small in size. Arab countries have not been able to produce large powerhouse financial institutions that could be a force in the international banking arena. They need to strengthen their position through consolidation in order to compete effectively with international banks. Therefore, the size of the banking sector in Arab countries, in absolute terms, is relatively small when compared to those of other developed countries.

Table 1: Regional and worldwide size ranking of selected Arab banks by the total assets

\begin{tabular}{|c|l|l|c|c|c|}
\hline Arab Rank & Bank Name & Country & Total Assets million US\$ & Country rank by assets & World rank by assets \\
\hline 1 & Qatar National Bank & Qatar & 82,955 & 1 & 255 \\
\hline 2 & National Commercial Bank & Saudi A. & 80,319 & 1 & 259 \\
\hline 3 & Emirates NBD & UAE & 77,499 & 1 & 267 \\
\hline 4 & National Bank of Abu Dhabi & UAE & 69,617 & 2 & 293 \\
\hline 5 & Al Rajhi Bank & Saudi A. & 58,884 & 2 & 345 \\
\hline 6 & National Bank of Egypt & Egypt & 51,447 & 1 & 385 \\
\hline 7 & Samba Financial Group & Saudi A. & 51,406 & 3 & 387 \\
\hline 8 & Abu Dhabi Commercial Bank & UAE & 50,027 & 1 & 398 \\
\hline 9 & National Bank of Kuwait & Kuwait & 48,912 & 2 & 405 \\
\hline 10 & Kuwait Finance House & Kuwait & 48,312 & 4 & 410 \\
\hline 11 & Riyad Bank & Saudi A. & 48,237 & 1 & 439 \\
\hline 12 & Arab Bank Group (Combined) & Jordan & 45,263 & 4 & 458 \\
\hline 13 & First Gulf Bank & UAE & 42,881 & 1 & 474 \\
\hline 14 & Attijariwafa Bank & Morocco & 41,380 & 5 & 516 \\
\hline 15 & Banque Saudi Fransi & Saudi A. & 37,461 & 1 & 847 \\
\hline \hline 35 & Commercial Bank of Syria & Syria & 18,550 & 1 & 929 \\
\hline 42 & Libyan Foreign Bank & Libya & 15,908 & 1 & 1943 \\
\hline 90 & Banque Internationale Arabe de Tunisie & Tunisia & 5,066 & 1 & 3469 \\
\hline 154 & Tadhamon International Islamic & Yemen & 1,711 & & \\
\hline
\end{tabular}

Source: Compiled by the researcher from Bankscope

Second, Out of 15 banks, there were 12 banks from 4 of the GCC countries. These 12 banks were among the biggest economies in Arab countries. Saudi Arabia, UAE, Qatar and Kuwait were $1^{\text {st }}, 2^{\text {nd }}, 5^{\text {th }}$ and $6^{\text {th }}$ biggest economies in terms 
of GDP. Third, none of the biggest 15 banks were from Libya, Syria, Tunisia, or Yemen. Even though, as mentioned earlier, the size of the banking sector in Arab countries, in absolute terms, was relatively small when compared to those of other developed countries, yet the banking sectors at the five countries were relatively even smaller. The largest bank in Egypt was the National Bank of Egypt ranked 385 in the world. Table 1 shows that the Commercial Bank of Syria, Libyan Foreign Bank, Banque Internationale Arabe de Tunisie and Tadhamon International Islamic were the biggest banks measured by total asset size in Syria, Libya, Tunisia and Yemen respectively. They were not among the top big banks and their world rank in 2010 was 846, 929, 1944 and 3469 in that order. Banks in Libya, Syria, Tunisia and Yemen did not exist among the big banks which reflected the poor GDP's volume, size of markets and the performance of all sectors in the five countries' economies. The performance of all business sectors was not the best and relative banks performance regionally is a reflection of what was happening in terms of markets' size, local investors' confidence, attraction of foreign investors and creation of jobs.

One measure of profitability is used in this section namely Return on Average Asset (ROAA). ROAA reflects a bank's management ability to utilize the bank's financial and real investment resources to generate profits, specifically to measure the profit earned per currency of assets. This ratio depends mainly on the bank's policy as well as some external factors related to the economy and government regulations. ROAA incorporates the external and internal factors that affect the bank's performance. It indicates which banks were the best in utilizing their size to make the highest return. The comparison among banks based on ROAA gives us an indication as to how efficient the management was in creating the best outcome by utilizing the input they have.

Table 2 ranks the most efficient banks and shows us fascinating observations. First, generally speaking the smaller banks were more efficient than bigger banks. Qatar National Bank which was the biggest in terms of size and first in term of income, ranked 27 according to ROAA. Second, Islamic banks were among the best performers indicating that they were utilizing their input to get the best output much more efficiently than commercial banks. This coincides with many studies that Islamic banks are more efficient than commercial banks in Arab countries. For example, Al-Muharrami (2008) uses DEA techniques to estimate technical, pure technical and scale efficiency, using an input orientation for GCC banks for the period 1993 to 2002. He highlighted interesting findings regarding the GCC banking market. First, smaller banks exhibited superior performance in terms of overall technical efficiency than did larger ones. Second, Islamic banks were more successful in both the adoption of the best available technology and choosing optimal levels of output.

Finally, Table 2 shows that there were no banks from Egypt, Libya, Tunisia and Yemen as the top best banks in terms of ROAA. This shows that, not only the bad investment environment in the 5 countries, but also the inefficiency of the banks' management teams.

Generally, the connection between the growth of economy and the performance of banks is straightforward. Kosmidou (2008), among others, found that the growth of GDP has a significant and positive impact on ROAA. Therefore, slow or zero growth of the GDP has an effect on the operation of the private sector including the financial institutions. Therefore, Table 2 does not include any bank out of 74 banks from the five countries because of the slow growth of the economies of those five countries.

Table 2: Top 15 Arab banks based on ROAA in 2010

\begin{tabular}{|c|l|c|c|c|}
\hline Rank & Bank Name & Country & ROAA \% & Ranking in size \\
\hline 1 & Citi Islamic Bank & Bahrain & 24.48 & 277 \\
\hline 2 & Seera Bank & Bahrain & 13.00 & 215 \\
\hline 3 & CSC Bank SAL & Lebanon & 11.21 & 257 \\
\hline 4 & Elaf Islamic Bank & Iraq & 11.11 & 255 \\
\hline 5 & Gulf Commercial Bank & Iraq & 8.07 & 251 \\
\hline 6 & Trust Bank Algeria & Algeria & 6.91 & 224 \\
\hline 7 & National Bank of Ras Al-Khaimah & UAE & 5.25 & 74 \\
\hline 8 & Bahrain Commercial Facilities & Bahrain & 4.93 & 222 \\
\hline 9 & Bank of Baghdad & Iraq & 4.75 & 223 \\
\hline 10 & Bank of Iraq & Iraq & 4.07 & 250 \\
\hline 11 & Gulf Bank Algeria & Algeria & 3.92 & 196 \\
\hline 12 & Credit Europe Bank (Dubai) & UAE & 3.71 & 239 \\
\hline 13 & Rajhi Bank & Saudi A. & 3.64 & 5 \\
\hline 14 & North Bank & Iraq & 3.61 & 197 \\
\hline 15 & United Arab Bank & UAE & 3.56 & 122 \\
\hline
\end{tabular}

Source: Compiled by the researcher from Bankscope 
After looking at the general individual ranking of each bank, the paper next makes a comparison based on an aggregate basis between two groups. The whole sample was split into two categories. The first category consists of 74 (65 commercial and 9 Islamic) banks in Egypt, Libya, Syria, Tunisia and Yemen; and the second category contains 241 (170 commercial and 71) Islamic banks in other 15 Arab countries. The comparison summarizes the growth and evolution of some financial variables and ratios. It compares the aggregate growth, performance and efficiency of 74 banks versus the remaining 241 banks.

Table 3 illustrates some fascinating observations: First, the total assets of both groups had grown over years; however, the total assets of 74 banks in the 5 countries grew at a lower pace compared to the total assets of 241 banks in the 15 countries. In 2010, their total assets were only US\$256,105 million representing $12.8 \%$ of the total. The slower growth of the 74 banks' total assets was a manifestation of the slow economic expansion in the five countries. Second, there was a constant growth in net income except for 2008 and 2009 of the 241 banks and for 2009 of the 74 banks. In 2010 , the total income of the 74 banks was US\$ 2,259 million representing only $8.8 \%$ of the total. Thus, both total assets and net income variables indicate that humble growth and performance of the 74 banks. These, two among other financial, variables were below the average of Arab countries indicating the size of the market and type of activities that are available for banks in these 5 countries to invest.

Third, most bankers and examiners will agree that the single greatest risk in banking is the risk of loan losses. This is because loans typically comprise a majority of the assets in most banks. It is not hard to imagine an entire year's worth of earnings being completely eliminated because of one or two large loans being charged off. Arab banks had considerable experience with bad loans as a result of the global financial crisis and because of slow economic growth for some countries. Examination of the breakdown of the balance sheets for both groups in Figure 5 shows that only $36.2 \%$ of the total assets of 74 banks in 2010 went to loans. The majority of their assets, 50.9\%, was invested in earning assets. This indicates that due to the slow economic growth in the five countries, their banks were trying to avoid involving themselves in risky loans and preferred to invest in other earning assets such as different types of securities. Due to the market conditions, their decision was to invest in other less risky instruments with lower return than providing loans to individuals and business' sectors. Therefore, the markets' conditions forced banks to make that decision.

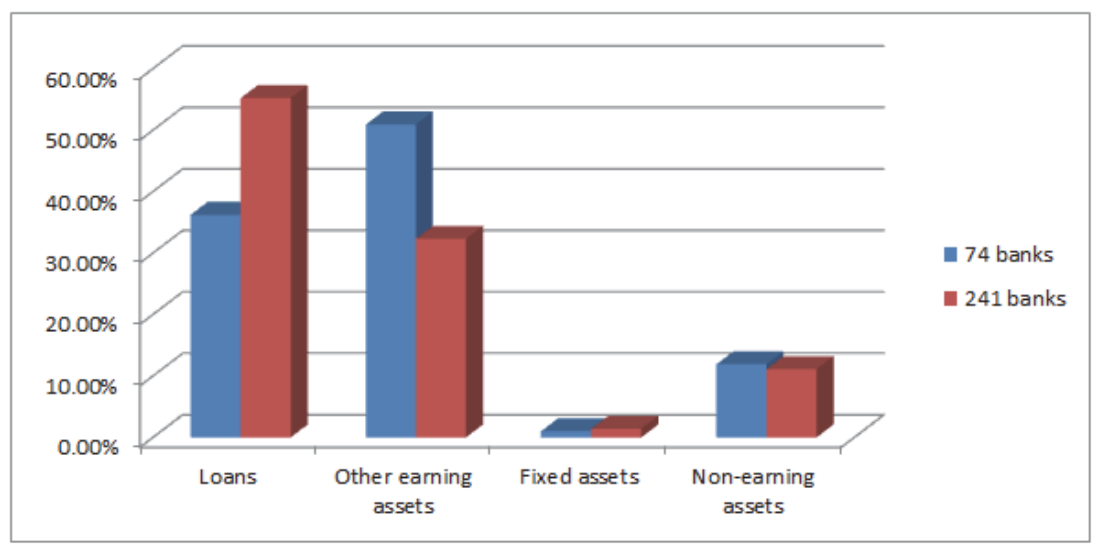

Figure 5: Comparative breakdown of the balance sheets items of 74 versus 241 banks in 2010 Source: Compiled by the author from Bankscope

There is a relationship between an economy's conditions and banks' Non-Performing Loans (NPL: those loans which are 90 days or more past due or in nonaccrual status). During an economic crisis, in order to restore the credibility among creditors and depositors, banks not only try to expand their equity bases, but also reduce their risk assets or change the composition of the assets portfolio. As a result of such defensive action, the business debtors are always targeted, thus preventing the overall economic growth. Thus, in consequence of poor economic conditions and the depressed economic growth, the level of NPL increases leading banks to be more reluctant to provide additional credits to the private sector. Therefore, the production sector is further weakened, resulting in decreases in aggregate demand. Again, even worse borrowers' conditions create more NPL.

Also, the high level of NPL requires banks to raise provision for loan loss that decreases the banks' revenue and reduces the funds for new lending. The cutback of loans impairs the business sector as they have difficulties in expanding their working capital, blocking their chances of resuming normal operation or growing. Unavailability of credit to finance 
firm's working capitals and investments might trigger the second round business failure which in turn worsens the quality of bank loans, resulting in a re-emerging of banking or financial failure. In the worst case, it triggers an endless vicious liquidity spiral.

Analysing the assets quality of these banks, the ratios show the overall of the following financial ratio: Loan Loss Reserve / Gross Loans, NPL / Gross Loans, Net Charge-off (NCO) / Average Gross Loans, and Nonperforming loans/ Equity. These entire ratios witnessed the superiority of 241 banks over the 74 banks in terms of the assets quality ratios. For example, in 2010 the nonperforming loans to the gross loans of the 241 banks were $5.52 \%$ versus $13.58 \%$ for the 74 banks.

The volume of NPL has declined for 15 countries' banks. That was evidenced by their shrinking provision expenses (or charges against earnings to build loan loss reserves) and therefore rising profits. Unfortunately, this improving regional trend is not emerging across the five countries. As illustrated in Table 3, nonperforming loans appear to have increased in volume and the ratio of nonperforming loans to total loans increased at a high rate at year-end 2010 reaching 13.58\% across all banks in the five countries. For 74 banks, the ratio climbed in 2009 and 2010 after a modest decline through 2004 to 2008. The increase in nonperforming loans signals the weakness and the recession that had faced the economies of the five countries. The slowdown in the five countries' gross domestic product could be the main factor that impacted banks' asset quality. As the GDP growth slows, the problems for the banking sector are far from over.

Fourth, examining the capital adequacy ratios, these ratios also demonstrated the supremacy of the 241 banks over the 74 banks. For instance, in 2010 the ratio of equity to total assets was $13.83 \%$ opposed to $9.26 \%$ for 241 banks and 74 banks respectively. The Basel Accord of 1988 attempted to deal with the diversity in institutional activities by applying different credit risk weights to different positions and by including in the base for the capital ratio a measure of the off-balance sheet exposures of the bank. In spite of these calibrations, the intent was not to determine an exact appropriate level of capital for the bank, but rather to provide a more flexible way of determining the minimum required level (see Basel Committee on Banking Supervision 1988). Banks are now classified as "adequately capitalized" if they meet the Basel requirements, but new distinctions among levels of capital were introduced. For example, a bank is "well capitalized" if it holds a certain buffer above the "adequate" levels. In contrast, a bank that falls under a specific level, set somewhat below the minimum "adequate" level, is determined to be "critically undercapitalized" and must be shut down by supervisors. An aggregate capital ratio of 74 banks would be considered to be moving from below the minimum adequate to adequate level of meeting the capital requirement condition.

Fifth, the operation ratios show the weak position of 74 banks. The 74 banks were worse managed and less efficient in terms of reducing cost, utilizing the size, and utilizing the available input to have an outstanding output. The profitability ratios were less; the return on average assets was $0.93 \%$ for 74 banks whereas the return on average assets was $1.40 \%$ for 241 banks in 2010 . As consequences of the bad economic conditions the profitability and the efficiency of these 74 banks in the 5 countries was affected.

Finally, investigating liquidity ratios gives us an indication about the liquidity risk. Liquidity risk is the probability the financial firm will not have sufficient cash and borrowing capacity to meet deposit withdrawals and other cash needs. If more than $60-70 \%$ of total assets are loaned out, the bank is considered to be highly illiquid. On the other hand, keeping too much liquidity in forms of cash or liquid assets has the advantage of being ready to meet the liquidity demand, yet liquid assets tend to award a lower return.

Liquidity risk, arising from the possible inability of a bank to accommodate decreases in liabilities or to fund increases on the assets' side of the balance sheet, is considered an important determinant of bank profitability. The loans market, especially credit to households and firms, is risky and has a greater expected return than other bank assets, such as government securities. Thus, one would expect that the fewer the funds tied up in liquid investments the higher we might expect profitability to be (Eichengreen and Gibson, 2001).

The liquidity ratios show that the 74 banks were keeping more liquid assets than the 241 banks. This could explain the lower return of the 74 banks in these five countries. However, keeping cash or liquid assets is not always an internal issue within a bank, rather it also depends on the market investment opportunities. Many banks keep too much cash or liquid assets with a lower return because of the limited or the lack of business prospects and chances. 
Table 3: Evolution of some of financial variables and financial soundness of 74 banks vs. of 241 banks (the amounts in millions US\$)

\begin{tabular}{|c|c|c|c|c|c|c|c|c|c|c|c|c|c|c|}
\hline & \multicolumn{2}{|c|}{2010} & \multicolumn{2}{|c|}{2009} & \multicolumn{2}{|c|}{2008} & \multicolumn{2}{|c|}{2007} & \multicolumn{2}{|c|}{2005} & \multicolumn{2}{|c|}{2000} & \multicolumn{2}{|c|}{1997} \\
\hline & $\begin{array}{c}15 \\
\text { countries } \\
\end{array}$ & \begin{tabular}{|c|}
5 \\
countries \\
\end{tabular} & $\begin{array}{c}15 \\
\text { countries }\end{array}$ & $\begin{array}{c}5 \\
\text { Countries } \\
\end{array}$ & \begin{tabular}{|c|}
15 \\
countries \\
\end{tabular} & \begin{tabular}{|c|}
5 \\
countries \\
\end{tabular} & $\begin{array}{c}15 \\
\text { countries } \\
\end{array}$ & \begin{tabular}{|c|}
5 \\
countries \\
\end{tabular} & $\begin{array}{c}15 \\
\text { countries } \\
\end{array}$ & \begin{tabular}{|c|}
5 \\
countries \\
\end{tabular} & $\begin{array}{c}15 \\
\text { countries } \\
\end{array}$ & \begin{tabular}{|c|}
5 \\
countries \\
\end{tabular} & $\begin{array}{c}15 \\
\text { countries }\end{array}$ & \begin{tabular}{|c|}
5 \\
countries
\end{tabular} \\
\hline Total Assets & $1,733,868$ & 256,105 & $\begin{array}{c}1,625,37 \\
2 \\
\end{array}$ & 242,892 & $1,535,811$ & 240,476 & $1,298,069$ & 198,301 & 714,509 & 120,954 & 388,042 & 76,650 & 287,251 & 64,085 \\
\hline $\begin{array}{l}\text { Deposits and } \\
\text { ST funding }\end{array}$ & $1,337,667$ & 213,546 & $\begin{array}{c}1,258,51 \\
3\end{array}$ & 200,958 & $1,205,933$ & 198,183 & $1,019,653$ & 169,831 & 548,317 & 103,032 & 319,609 & 66,523 & 240,570 & 55,255 \\
\hline Equity & 239,718 & 23,709 & 219,997 & 21,848 & 194,644 & 18,693 & 164,746 & 13,662 & 94,930 & 8,305 & 41,237 & 4,544 & 26,987 & 3,643 \\
\hline \begin{tabular}{|l|} 
Net Income \\
\end{tabular} & 23,438 & 2,259 & \begin{tabular}{|l|}
19,748 \\
\end{tabular} & 2,013 & 23,100 & 2,144 & 26,919 & 1,364 & 17,645 & 581 & 5,156 & 513 & 3,776 & 346,933 \\
\hline \multicolumn{15}{|l|}{ Assets Quality } \\
\hline \begin{tabular}{|l|} 
Loan Loss \\
Reserve / \\
Gross Loans \\
\end{tabular} & 3.99 & 15.05 & 3.74 & 14.66 & 2.76 & 15.91 & 2.80 & 14.69 & 3.78 & 14.48 & 8.23 & 11.28 & 7.82 & 11.43 \\
\hline $\begin{array}{l}\text { NPL / Gross } \\
\text { Loans } \\
\end{array}$ & 5.52 & 13.58 & 4.83 & 11.54 & 2.78 & 8.95 & 2.61 & 14.71 & 3.19 & 20.79 & 9.86 & 17.57 & 9.46 & 11.25 \\
\hline \begin{tabular}{|l|} 
NCO / Average \\
Gross Loans
\end{tabular} & 0.64 & 0.72 & 0.26 & 0.24 & 0.13 & 0.33 & 0.20 & 0.42 & 0.49 & 0.59 & 0.45 & 0.41 & 0.53 & 0.41 \\
\hline NPL / Equity & 23.21 & 72.47 & 20.86 & 56.13 & 13.30 & 42.27 & 11.09 & 110.01 & 13.11 & 165.39 & 46.12 & 23.20 & 42.05 & 16.25 \\
\hline \multicolumn{15}{|l|}{ Capital } \\
\hline \begin{tabular}{|l} 
Equity / Total \\
Assets
\end{tabular} & 13.83 & 9.26 & 13.54 & 9.00 & 12.67 & 7.77 & 12.69 & 6.89 & 13.29 & 6.87 & 10.63 & 5.93 & 9.39 & 5.69 \\
\hline \begin{tabular}{|l|} 
Capital Funds / \\
Liabilities
\end{tabular} & 17.55 & 10.80 & 17.10 & 10.27 & 15.50 & 8.64 & 15.27 & 7.83 & 15.73 & 7.48 & 12.02 & 6.30 & 10.59 & 6.05 \\
\hline \begin{tabular}{|l|} 
Equity / Net \\
Loans
\end{tabular} & 24.82 & 25.51 & 23.99 & 24.20 & 21.80 & 20.28 & 24.73 & 18.99 & 26.34 & 16.93 & 24.52 & 11.34 & 20.79 & 12.72 \\
\hline \begin{tabular}{|l|} 
Equity / Cust \\
and Short Term \\
Funding \\
\end{tabular} & 17.16 & 11.06 & 17.37 & 10.80 & 15.25 & 9.43 & 15.39 & 8.04 & 16.11 & 8.06 & 11.35 & 6.83 & 11.15 & 6.59 \\
\hline \multicolumn{15}{|l|}{ Operations } \\
\hline $\begin{array}{l}\text { Net Interest } \\
\text { Margin } \\
\end{array}$ & 3.03 & 2.45 & 3.08 & 2.62 & 3.16 & 2.61 & 3.22 & 2.07 & 3.47 & 2.01 & 2.98 & 1.52 & 3.18 & 1.60 \\
\hline \begin{tabular}{|l|} 
Return on \\
Average Assets \\
(ROAA)
\end{tabular} & 1.40 & 0.93 & 1.26 & 0.87 & 1.63 & 0.98 & 2.45 & 0.78 & 2.77 & 0.52 & 1.38 & 0.71 & 1.38 & 0.61 \\
\hline \begin{tabular}{|l|} 
Return on \\
Average Equity \\
(ROAE)
\end{tabular} & 10.25 & 10.12 & 9.58 & 10.16 & 12.86 & 13.27 & 18.76 & 11.10 & 21.83 & 7.33 & 13.10 & 11.90 & 14.94 & 11.03 \\
\hline \begin{tabular}{|l|} 
Cost to Income \\
Ratio \\
\end{tabular} & 39.59 & 39.97 & 40.60 & 46.63 & 39.42 & 40.75 & 36.28 & 53.29 & 35.05 & 43.85 & 47.79 & 49.09 & 49.70 & 59.87 \\
\hline \multicolumn{15}{|l|}{ Liquidity } \\
\hline \begin{tabular}{|l|} 
Net Loans I \\
Total Assets \\
\end{tabular} & 55.29 & 36.31 & 55.90 & 36.78 & 56.24 & 37.94 & 51.07 & 36.29 & 50.30 & 40.43 & 43.34 & 52.26 & 45.18 & 44.68 \\
\hline $\begin{array}{l}\text { Net Loans / } \\
\text { Customer and } \\
\text { ST Funding }\end{array}$ & 70.90 & 43.56 & 72.07 & 44.42 & 70.70 & 45.99 & 64.47 & 42.37 & 64.64 & 47.45 & 51.83 & 60.22 & 53.90 & 51.82 \\
\hline $\begin{array}{l}\text { Net Loans / Tot } \\
\text { Dep and Bor }\end{array}$ & 66.37 & 44.25 & 68.47 & 44.77 & 66.80 & 48.00 & 60.82 & 46.79 & 60.86 & 50.16 & 51.13 & 57.59 & 52.76 & 50.72 \\
\hline $\begin{array}{l}\text { Liquid Assets / } \\
\text { Cust and ST } \\
\text { Funding } \\
\end{array}$ & 27.77 & 43.68 & 27.73 & 46.65 & 26.47 & 51.25 & 33.17 & 51.35 & 33.34 & 39.19 & 46.79 & 25.34 & 48.96 & 33.64 \\
\hline
\end{tabular}

\section{Source: Compiled by the researcher from Bankscope}

Since GCC countries are the richest in terms of their GDP and have the highest GDP per capita; then, it is expected that the banks in GCC countries outperform other Arab banks in other Arab countries. Therefore, this would be considered as an unfair comparison. Therefore, Table 4 presents the comparison between 74 banks in five countries versus 142 banks in nine Arab countries excluding banks in GCC countries. The results in Table 4 are almost the same as in Table 3 . The performances of 74 banks in five countries were much inferior compare to the 142 banks in nine countries. These results approve the earlier findings that the economic conditions and the business environments at these five countries were very bad. 
Table 4: Evolution of some of financial variables and financial soundness of 74 banks vs. of 142 banks (the amounts in millions US\$)

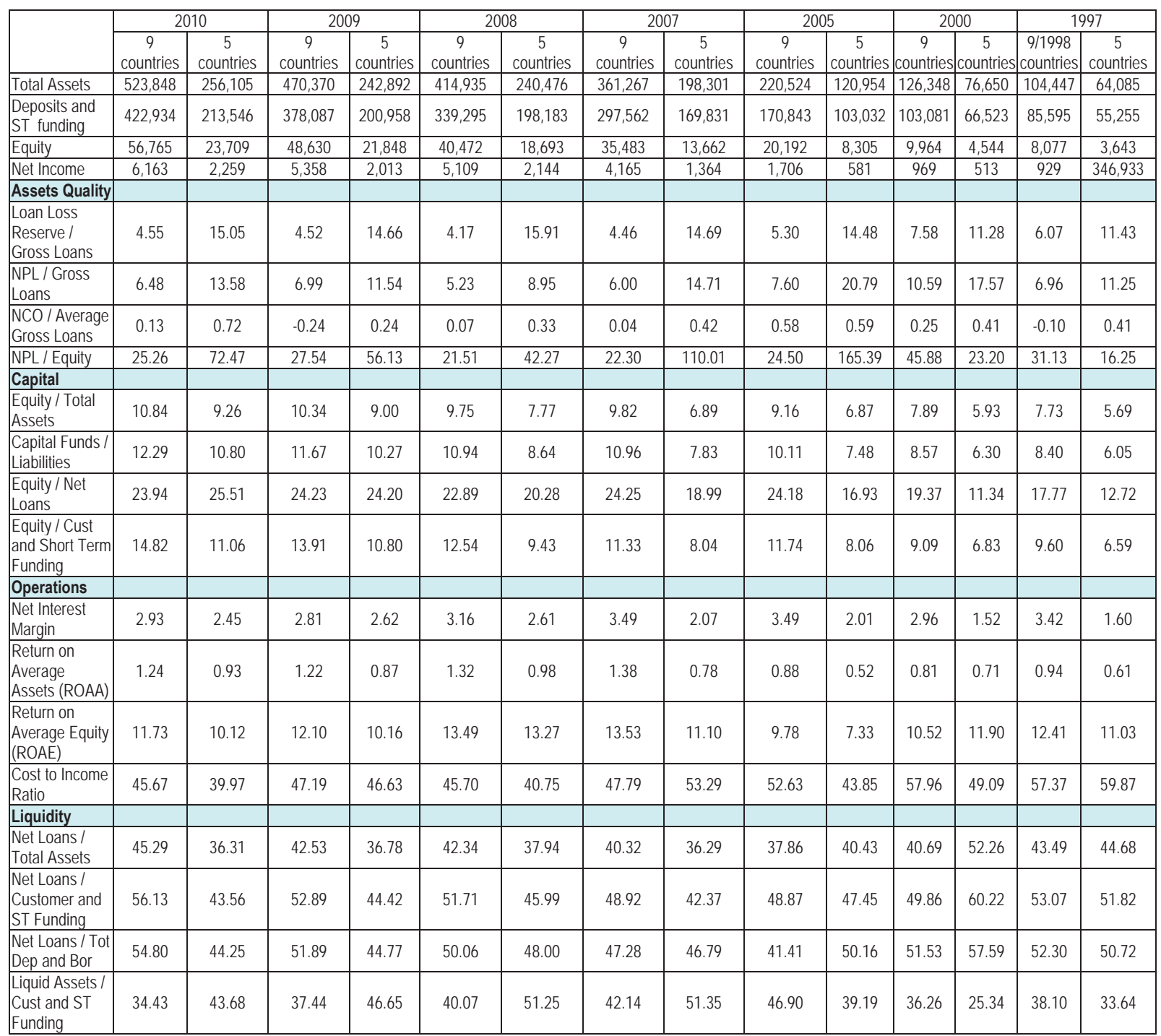

Note: ST = Short Term; NPL = Non-performing loans; NCO = Net Charge-off; Cust. = Customer; Tot Dep = Total Deposit

Source: Compiled by the researcher from Bankscope

\section{Concluding Remarks}

Investigating the growth and evolution of Arab banks, one would say that overall banks in Arab countries are doing extremely well in their performance. Therefore, the economy and the business environment are very good as well. However, getting closer to the top performers, one can notice that the top performing banks were not coming from the banks in five countries (Egypt, Libya, Syria, Tunisia and Yemen), rather they were coming from the GCC countries. First, the top four banks according to the size of total assets are from Qatar and Saudi Arabia. Second, the best four banks according to their net income are from Qatar, Saudi Arabia and UAE. Finally, 22 banks out of 30 most efficient banks, according to ROAA, were from the six GCC countries. Therefore, 104 GCC commercial and Islamic banks, out of total 315 Arab banks, mainly were lifting the frontier upward.

According to Banker (2010) 84 Arab banks entered the list of the world's top 1,000 worldwide banks. 58 of those Arab banks were based in the GCC. GCC Banks had a fairly diversified portfolio. GCC Banks have placed the greatest proportion of their funds in lending to the retail, wholesale trade and construction sectors. The GCC countries, in other words, lived to some extent in their own world, with their own prosperity, even apart from the rest of the Arab countries. 
In contrast, the majority of banks in the five countries were mainly below the average in their size and performance. Their ranking, regionally and globally, in terms of size, performance and efficiency were weak. The regional and world ranking of these banks gives a glimpse of the business atmosphere in these countries. The governments in those five countries could not create a good business environment, attract foreign investors and generate the confidence in local investors to invest in their countries. They did not invest properly to get their people out of poverty. The close environment of the economy in general could not create a sustainable growth of employment. Therefore, the unemployment rate was high in most of those five highly populated countries. As a consequence, the demonstrations kicked off a wave of protests seeking for changes. The demonstrators were out seeking for the change of power with a hope that change would bring them prosperity and a better life.

All in all, banks' performance is the reflection of the size and type of business environment within the economy. Banks' indicators can give a good, quick insight into the economy, the business environment and foreign and local investors' confidence in a country. The paper illustrates that wherever banks' performances were good that is an indication of the openness of the market for investment and the healthy environment for all business sectors. On the other hand, slow growth in size and bad performance of banks indicate the lack of economic growth, a highly controlled private sector, poor investment environment and the lack of attracting foreign investors. As a result, there will be a weak labour market leading to high unemployment rate. This is exactly what happened in five countries (Egypt, Libya, Syria, Tunisia, and Yemen). Other Arab countries that are following the same strategy will face the same fate.

The analysis suggests that a bank's performance will depend on the nature of the economic conditions as well as on the individual bank's business strategy. General economic conditions may end up being more important than a bank's risk management and general business practices, as well as its customer base in accounting for the variability of its performance. Bank performance has been heavily dependent upon local economic conditions. Many researchers (see Samolyk, 1994) observe that banking sector problems may be constrained by the poor economic activity in financially distressed regions, whereas no such relationship has been found in financially healthy regions.

Overall, the connection between economic conditions and the performance of banks is straightforward. From the analysis, economic conditions have had significant effects on of the 74 banks. 74 banks' performance appears not only to be a good reflection of the economic conditions of the five countries, but also, it was a significantly good predictor of what would happen if things were kept moving at the same pace of growth.

The Arab Spring was shocking news for many governments; however, it was even more important that the Arab world continued to prioritize economic, social and human development; the alleviation of poverty and illiteracy; creation of job opportunities and health care. Banks' size and performance were good indicators and predictors of what had happened in a number of Arab countries. As an extension to this study, the author suggests conducting an empirical study using parametric techniques, to determine exactly which factors affected the Arab Spring.

\section{References}

Al-Muharrami, S., Matthews, K., and Khabari, Y. (2006). "Market structure and competitive conditions in the Arab GCC banking system." Journal of Banking \& Finance, 30. 12, 3487-3501.

Al-Muharrami, S. (2008). "An examination of technical, pure technical and scale efficiencies in GCC banking." American Journal of Finance and Accounting, 1, No. 2, 152-166.

Bankscope (2011). Capital Intelligence, Bankscope CD Rom Databases.

Basel Committee on Banking Supervision (1988). International Convergence of Capital Measurement and Capital Standards, Bank for International Settlements, Basel, Switzerland.

Bhattacharya, B. (1993). "The Gulf banking industry trends, patterns and prospects in 1990." working paper, Qatar Central Bank, Doha.

Cameron, R. (1967). Banking in the Early Stages of Industrialization. Oxford University Press, New York.

Chong, B. S., and Liu, M.-H. (2009). "Islamic Banking: Interest-Free or Interest-Based?" Pacific-Basin Finance Journal, 17, 125-144.

Choudhuri, N. I. (1995). "An evaluation of the impact of reforms in the financial sector." Bank Parikrama, XXX, No. 3 and 4, 1-45.

DeGregorio, J. and Gudotti, P. (1995). "Financial development and economic growth." World Development, 23, No. 3, $433-448$.

Eichengreen, B. and Gibson, H.D. (2001). "Greek banking at the dawn of the new millennium." CERP Discussion Paper 2791, London.

Goldsmith, R. W. (1969). Financial Structure and Economic Development. Yale University Press, New Haven.

ILO (2011) International Labor Organization (ILO). Available at http://www.ilo.org/global/about-the-ilo/press-and-media-centre/insight/ WCMS_154078/lang--en/index.htm (accessed 20 May 2013).

King. R. G. and Levine, R. (1993). "Finance, entrepreneurship and growth: Theory and evidence." Journal of Monetary Economics, 32, 512-542.

Kosmidou, K. (2008). "The determinants of banks' profits in Greece during the period of EU financial integration." Managerial Finance, 34, No. 3 , $146-159$

Mckinnon, R. I. (1973) "Money and Capital in Economic Development." Washington, D.C., The Brookings Institution.

Samolyk, K. A. (1994). "U.S. banking sector trends: Assessing disparities in industry performance." Economic Review-Federal Reserve Bank of Cleveland, Second Quarter, 30, 2-17.

Shaw, E. S. (1973). Financial Deepening in Economic Development. Oxford University Press, New York. 